\title{
The Effect of Teacher Professionalism and Competency on the Quality of Education in the City of Langsa
}

\author{
Suhartini $^{1}$, Sri Milfayetty ${ }^{2}$, Arif Rahman ${ }^{3}$ \\ ${ }^{1,2,3}$ Education Management, Universitas Negeri Medan, Indonesia \\ titinildani69@gmail.com,milfayetty@yahoo.com,arifr81@gmail.com
}

\begin{abstract}
Improving teacher professionalism and competence is one of the main functions of the education and culture office as an effort to improve the quality of education in a region. This study looks at the influence of professionalism and competence of teachers in improving the quality of education in Langsa City. As for the sample, 50 Langsa public junior high schools, 2 Langsa public junior high schools and 50 Langsa public junior high schools 3 teachers were selected. The results showed that professionalism and competence simultaneously have a positive and significant effect on the quality of education in Langsa City because the value of $F_{\text {count }}>F_{\text {table }}$ is $(28,354>2,960)$. Professionalism partially has a positive and significant effect on the Quality of Education in Langsa City because the value of $t_{\text {count }}>t_{\text {table }}(2,212>1,680)$. Teacher competence partially has a positive and significant effect on the quality of education in Langsa City because the value of $t_{\text {count }}>t_{\text {table }}(54,939>1,680)$.
\end{abstract}

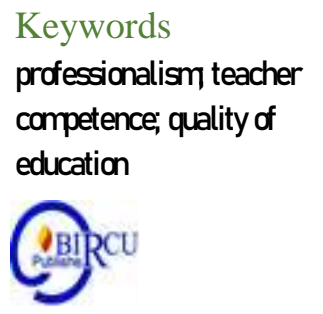

\section{Introduction}

The Office of Education and Culture is an element implementing government affairs in the field of education and culture led by a head of service who is under and responsible to the head of the region. Langsa City Education Office has five (5) fields of work, namely (1) Primary School Sector, (2) Junior High School Sector, (3) Non-Formal Education Sector, (4) Teacher and Education Personnel Sector, and (5) Culture Sector. In this case the head of the service as someone who is given the task of managing the agency is responsible for improving the quality of education in the local city. Especially with regard to the head of the department, teachers must have the ability to improve teacher performance in both primary and junior secondary schools, through empowering human resources.

According to Saputra (2019) Education is a variable that determines the quality of human resources of a nation. So it is the responsibility of the government to ensure the implementation of education with good quality/quality. Isa (2005: 41) suggests that teachers or educators are true leaders, wise guides and directors, who produce figures and leaders of the ummah. Teachers are professional educators with the main task of educating, teaching, guiding, directing, training, assessing, and evaluating students in primary and secondary education. Silalahi and Hutauruk (2020) Stated that in other words, a child's brain is like an empty bottle that is ready to be filled with all the knowledge and wisdom of a teacher. Based on this assumption, many teachers carry out learning activities by transferring knowledge from teacher to student.

Furthermore, Usman (2008: 50) defines a professional teacher as a person who has special abilities and expertise in the field of teacher training so that he is able to carry out his duties and functions as a teacher with maximum ability. Another opinion is expressed by Sholeh (2007: 45), which states that in the education process, teachers not only carry 
out the function of transfer of knowledge, but also function to instill values and build students' character (character building) sustainable. In Islamic terminology, guru is termed murabby, a root word with rabb which means God. So, the function and role of teachers in the education system is one of the manifestations of divine nature. Such is the position of guru, to the extent that God, in the sense of being rabb, identifies Himself as rabbul.alamin, the Supreme Master, Teacher of the entire universe. For this reason, the first duty imposed on each servant as a disciple of the Supreme Master is to study and seek knowledge. After that, everyone who already has knowledge has an obligation to teach it to others. Thus, the teaching profession is an obligation which is a manifestation of worship. As a consequence, whoever hides a knowledge has stepped into the abyss of hellfire.

Responding to what has been stated by Sholeh, the teaching profession is a job that has the value of glory and worship. Teaching is an obligation for everyone who has knowledge. Furthermore, considering that teaching is an obligation for everyone who has knowledge, it is appropriate for people who do not convey their knowledge to result in sins for themselves. Furthermore, Sholeh (2007: 67) says that on the other hand, the teaching profession is an obligation, only imposed on everyone who is knowledgeable. In other words, the teaching profession must be based on the existence of competencies with certain academic qualifications.

Teaching, for someone who does not have the professional competence for that, it will result in sin. Then, if something is done by something that is not an expert, then wait for it to be destroyed .. A fragment of the hadith of the Prophet Muhammad, this seems to give a warning to teachers who do not meet their professional competence. From the explanation given by Sholeh, the author can conclude that the teaching profession is an obligation that is imposed only on knowledgeable people. Thus, the teaching profession must be based on the existence of certain competencies and qualifications for everyone who wants to teach.

According to Sholeh (2007: 69), conceptually, the two conditions above provide two principles in the context of talking about the professions of teachers and lecturers. First, there is a spirit of soul calling, devotion and worship. The teaching profession is a profession that has a specialty in shaping the character and civilization of a nation with dignity and requires expertise, idealism, wisdom and exemplary over a long period of time. Second, there is a principle of professionalism, the existence of competence and academic qualifications required, and there is an appreciation for the profession that is carried out. So the principles of idealism and calling of souls and principles of professionalism must underlie every struggle to uplift the dignity of teachers and lecturers. Thus the professions of teachers and lecturers are closed professions that must be in line with the principles of idealism and professionalism in a balanced manner. Do not let the impact on the struggle and the prominence of the professionalism aspect result in the creation of a lifestyle of materialism and pragmatism that negates idealism and the calling of the soul.

Conceptually, teacher performance according to Johson (2009: 48), includes three aspects, namely; (a) professional abilities, (b) social skills, and (c) personal abilities (personal). Realizing the importance of professionalism in education, Tafsir (2010: 22) defines professionalism as an understanding that teaches that every job must be done by a professional person. However, looking at the existing reality, the existence of professional teachers is very far from what they aspire to.

The proliferation of low-quality schools gives a sign that professional teachers are just a discourse that has not been realized evenly in all education in Indonesia. This raises a concern that does not only come from the teachers, but even ordinary people also comment on the irregularities of the existing education and teaching staff. This fact inspires the 
government by making formulations to improve teacher qualifications through empowerment and improvement of teacher professionalism from training to instructions so that teachers have a minimum educational qualification of Strata 1 (S1). The new problem is that teachers only understand these instructions as a formality to meet the demands of administrative needs. Some of the phenomena or problems that researchers can observe in several schools in Langsa City, including the existing teachers, are basically not fully categorized as professional teachers and the contribution to students is not paid much attention and even is neglected. Teacher competence is also in the poor category, this is evidenced by the lack of teachers who pass the teacher competency test (UKG).

\section{Research Methods}

The population of this study were 250 teachers at SMP N 1 Langsa City, SMP N 2 Langsa City, and SMP N 3 Langsa City, totaling 250 people. above 100, then 15-25 percent can be sampled, in this study the authors took 20 percent of the population to be sampe so that the sample in this study amounted to 50 teachers.

The data analysis technique used in this study is Multiple Regression Analysis. This analysis technique begins with data preparation, namely the tabulation process of the data and then the data is to facilitate researchers, the data will be processed with the SPSS Version 20.00 program. Furthermore, data analysis to see the relationship between intellectual ability and work motivation as independent variables on teacher performance as the dependent variable, the researchers used the multiple linear analysis formula, namely: $\mathrm{Y}=\mathrm{a}+\mathrm{b} 1 \mathrm{X} 1+\mathrm{b} 2 \mathrm{X} 2+\mathrm{b} 3 \mathrm{X} 3+\mathrm{E}$.

\section{Results and Discussion}

\subsection{The Influence of Professionalism on the Quality of Education in Langsa City}

To know partially the effect of teacher professionalism on the quality of education in Langsa City can be seen in Table 1 below.

Table 1. Coefficients ${ }^{(a)}$ Professionalism

\begin{tabular}{|l|l|r|r|r|r|r|}
\hline \multirow{2}{*}{ Model } & & \multicolumn{2}{|c|}{$\begin{array}{c}\text { Unstandardized } \\
\text { Coefficients }\end{array}$} & \multicolumn{1}{c|}{$\begin{array}{c}\text { Standardized } \\
\text { Coefficients }\end{array}$} & $\mathrm{t}$ & Sig. \\
\cline { 3 - 7 } & & \multicolumn{1}{|c|}{ B } & Std. Error & \multicolumn{1}{c|}{ Beta } & & \\
\hline 1 & (Constant) & 11.439 & 4.427 & & 2.584 & .013 \\
\hline & Professionalism & .139 & .063 & .194 & 2.212 & .032 \\
\hline
\end{tabular}

a. Dependent Variable: Quality of Education - Results of data processing-2014

Based on Table 1 above, it is known that the ability $t_{\text {count }}$ value is 2,212 and a significance value of 0.032 , while the $t_{\text {table }}$ value at the $95 \%$ confidence level $(\alpha: 0.05)$ with $\mathrm{N}-3=50-3=47$ is 1,680 , so it can be noticed in Figure 1 below. 


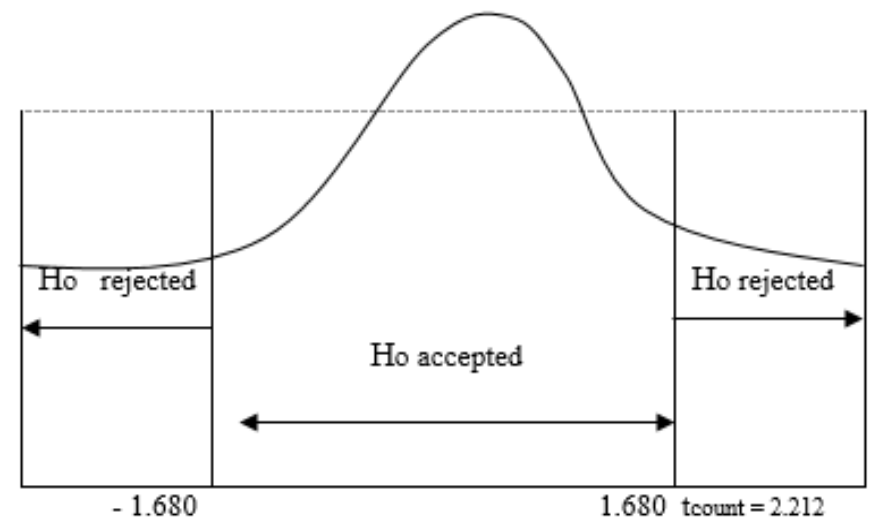

Figure 1. Testing the Professionalism Hypothesis on the Quality of Education

From Figure 1 above it is known that the value of tcount $>$ ttable $(2.212>1.680)$, it is decided that the regression coefficient is significant or $\mathrm{H}_{0}$ is rejected and accepts the hypothesis in this study, namely that the variable professionalism partially has a positive and significant effect on the quality of education in Langsa City. This can also be proven from the value of Probability $=0.032$; or $\mathrm{P}<0.05$; means that the regression coefficient of professionalism is partially significant at the $95 \%$ confidence level $(\alpha: 0,05)$.

\subsection{The Effect of Teacher Competence on the Quality of Education in Langsa City}

To know partially the effect of teacher competence on the quality of education in Langsa City can be seen in Table 2 below.

Table 2. Coefficients ${ }^{(a)}$ Teacher Competence

\begin{tabular}{|c|c|c|c|c|c|c|}
\hline \multirow[t]{2}{*}{ Model } & & \multicolumn{2}{|c|}{$\begin{array}{l}\text { Unstandardized } \\
\text { Coefficients }\end{array}$} & \multirow{2}{*}{$\begin{array}{c}\begin{array}{c}\text { Standardized } \\
\text { Coefficients }\end{array} \\
\text { Beta }\end{array}$} & \multirow[t]{2}{*}{$\mathrm{t}$} & \multirow[t]{2}{*}{ Sig. } \\
\hline & & B & Std. Error & & & \\
\hline 1 & (Constant) & 11.439 & 4.427 & & 2.584 & .013 \\
\hline & Teacher Competence & .358 & .060 & .567 & 5.939 & .000 \\
\hline
\end{tabular}

a. Dependent Variable: Quality of Education - Results of Data Processing-2014

Based on Table 2 above, it is known that the $t_{\text {count }}$ value of teacher competence is

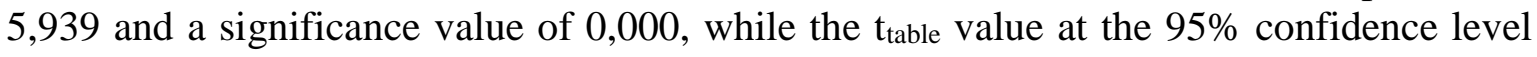
$(\alpha: 0,05)$ with $N-3=50-3=47$ is 1,680 , so it can be noted in Figure 2. below. 


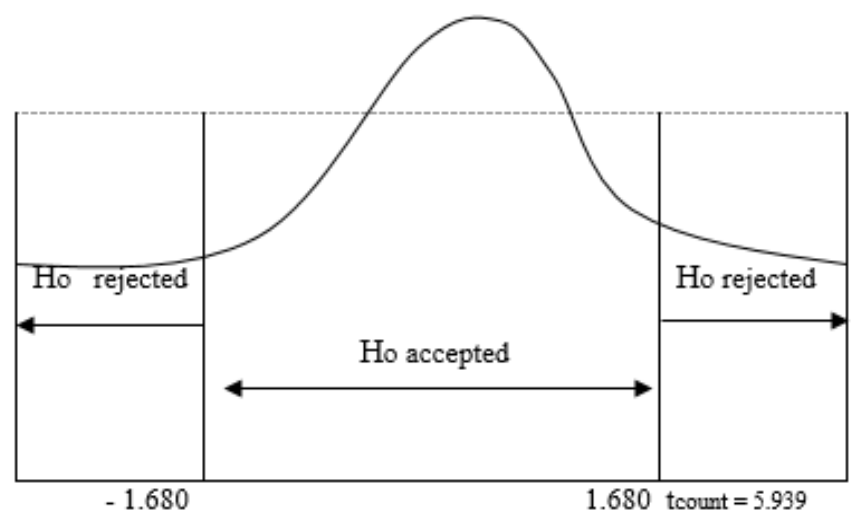

Figure 2. Hypothesis Test of Teacher Competence on Education Quality

From Figure 2 above, it is known that the value of tcount> ttable $(5,939>1,680)$, then it was decided that the regression coefficient was significant or $\mathrm{H}_{0}$ was rejected and accepted the hypothesis in this study that the teacher competency variable partially had a positive and significant effect on the quality of education in Langsa City. This can also be proven from the value of Probability $=0.000$; or $\mathrm{P}<0.05$; This means that the teacher competency regression coefficient is partially significant at the $95 \%$ confidence level $(\alpha$ : $0,05)$.

\section{Conclusion}

1. Professionalism and competence simultaneously have a positive and significant effect on the quality of education in Langsa City because the value of Fcount> Ftable is $(28,354>2,960)$.

2. Professionalism partially has a positive and significant effect on the Quality of Education in Langsa City because the value of tcount $>$ ttable $(2,212>1,680)$.

3 . Teacher competence partially has a positive and significant effect on the quality of education in Langsa City because the value of tcount $>$ ttable $(54,939>1,680)$.

\section{Suggestion}

1. The research results show that the professionalism and competence of teachers have an effect on the quality of education. Therefore, it is possible to pay attention to the Head of the Office and also the Principal of the School in Langsa City so that the quality of education can continue to improve.

2. The next head researcher would be able to add other variables if he wanted to do similar research.

\section{References}

Arifin, H.M. (2005). Kapita Selekta Pendidikan (Islam dan Umum), Jakarta: Bumi Aksara, Cet. Ke-3.

Arikunto, Suharsimi. (2002). Prosedur Penelitian Suatu Pendekatan Praktik, Jakarta: Rineka Cipta, Cet. Ke-12.

Departemen Pendidikn dan Kebudayaan. (2002). Kamus Besar Bahasa Indonesia, Jakarta:Balai Pustaka, Cet. Ke- 2.

Hamalik, Oemar. (2006). Pendidikan Guru Berdasarkan Pendekatan Kompetensi, Jakarta: PT. Bumi Aksara, Cet, Ke-4. 
Isa, Kamal Muhammad. (2000). Manajemen Pendidikan Islam, Jakarta: PT. Fikahati Anesta, Cet. Ke-1.

Mulyasa, E. (2008). Standar Kompetensi dan Sertifikasi Guru, Bandung: PT. Remaja Rosda Karya: Bandung, Cet. Ke-3. . (2000). Psikologi Pendidikan, Jakarta: Pedoman Ilmu Jaya, Cet. Ke2.

Saputra, A. (2019). Allocation of Education Budget in Indonesia. Budapest International Research and Critics Institute-Journal (BIRCI-Journal), 142-148.

Sholeh, Asrorun, Ni.am. (2006). Membangun Profesionalitas Guru Analisis Kronologis atas Lahirnya Undang-Undang Guru dan Dosen, Jakarta: eLSAS, Cet. Ke-1.

Silalahi, T. F., Hutauruk, A. F. (2020). The Application of Cooperative Learning Model during Online Learning in the Pandemic Period. Budapest International Research and Critics Institute-Journal (BIRCI-Journal), 1683-1691.

Slameto. (2003). Belajar dan Faktor-Faktor yang Mempengaruhinya, Jakarta: Rineka Cipta, Cet. Ke-4.

Soetjipto dan Raflis Kosasi. (2004). Profesi Keguruan, Jakarta: PT. Rineka Cipta, Cet. Ke2.

Sudjana, Nana, Dasar-dasar Pproses Belajar Mengajar, Bandung: PT. Sinar Baru Algesindo, 2000, Cet. Ke-4.

Sukardi, Dewa, Ketut, Bimbingan dan Penyuluhan Belajar di Sekolah, Surabaya: Usaha Nasional, 2000, Cet. Ke-1.

Suryabrata, Sumardi, Psikologi Pendidikan, Jakarta: PT. Raja Grafindi Persada, 2002, Cet. $\mathrm{Ke}-2$.

Syah, Muhibbin, Psikologi Belajar, Jakarta: Logos Wacana Ilmu, 2000, Cetakan Ke-2.

Tilaar, H.A.R, Membenahi Pendidikan Nasional, Jakarta: PT. Rineka Cipta, 2002, Cet. Ke1.

Undang-Undang Republik Indonesia No. 14 Tahun 2005, Tentang Guru dan Dosen, (2006). Bandung: Citra Umbara, Cet. Ke-1.

Usman, M. Uzer. (2006). Menjadi Guru Profesional, Bandung: PT. Remaja Rosda Karya, Cet. Ke-20.

Winkel, W.S. (1996). Psikologi Pengajaran, Jakarta: Grasindo, Cet. Ke-4.

Yamin, Martinis. (2007). Profesionalisasi Guru dan Implementasi KTSP, Jakarta: Gaung Persada Press, Cet. Ke-2.

Zurinal Z. Dan Wahdi Sayuti. (2006). Ilmu Pendidikan, Jakarta: UIN Jakarta Press, Cet. $\mathrm{Ke}-1$. 